\title{
Effects of CSN3 and LGB gene polymorphisms on production traits in beef cattle
}

\author{
Rogério A. Curi ${ }^{1}$, Henrique N. de Oliveira ${ }^{2}$, Marcos A. Gimenes ${ }^{1}$, Antonio C. Silveira ${ }^{2}$ \\ and Catalina R. Lopes ${ }^{1}$ \\ ${ }^{1}$ Universidade Estadual Paulista 'Júlio de Mesquita Filho', Instituto de Biociências, \\ Departamento de Genética, Botucatu, SP, Brazil. \\ ${ }^{2}$ Universidade Estadual Paulista 'Júlio de Mesquita Filho', Faculdade de Medicina, Departamento \\ de Melhoramento Zootécnico e Nutrição Animal, Veterinária e Zootecnia, Botucatu, SP, Brazil.
}

\begin{abstract}
The objective of the present study was to estimate the allele and genotype frequencies of the CSN3/Hinfl and LGB/Haelll gene polymorphisms in beef cattle belonging to different genetic groups, and to determine the effects of these polymorphisms on growth and carcass traits in these animals, which are submitted to an intensive production model. Genotyping was performed on 79 Nelore, 30 Canchim (5/8 Charolais $+3 / 8$ Zebu) and 275 crossbred cattle originating from the crosses of Simmental $(n=30)$ and Angus $(n=245)$ sires with Nelore females. Body weight, weight gain, dressing percentage, longissimus dorsi area and backfat thickness were fitted using the GLM procedure, and least square means of the genotypes were compared by the $F$ test. The results showed that the CSN3/Hinfl and LGB/Haelll polymorphisms did not have any effect on growth or carcass traits $(p>0.05)$.
\end{abstract}

Key words: beef cattle, polymorphisms, candidate gene, growth, carcass.

Received: April 5, 2004; Acceptec: September 28, 2004.

"Super-young" steers are animals finished on feedlot immediately after weaning and slaughtered as 13 montholds at the most, weighing at least $450 \mathrm{~kg}$. These animals should also have backfat thickness above $3.0 \mathrm{~mm}$, which, associated with the animals' youth, will guarantee the quality of meat and its by-products. This system takes advantage of maximum biological efficiency, which can basically be defined as live weight gain over energy intake. It provides an excellent model of intensive cattle rearing.

The $\kappa$-casein (CSN3) and $\beta$-lactoglobulin (LGB) genes are expressed in milk and are important in the evaluation of the milk production potential and milk fat and protein percentage, indicating a maternal ability in beef cattle and therefore representing candidate genes for growth traits. In addition, these genes can also be associated with other loci that have a direct influence on growth. Polymorphisms of these genes have been associated with milk production and quality and weight gain until weaning in dairy cattle. However, the results of these studies are contradictory. On the other hand, the effects of milk protein

Send correspondence to Rogério A. Curi. Universidade Estadual Paulista 'Júlio de Mesquita Filho', Instituto de Biociências, Departamento de Genética, Rubião Jr., 18.618-000 Botucatu, SP, Brazil. E-mail: rogcuri@btu.flash.tv.br. polymorphisms on production traits in beef cattle have been little investigated. Moody et al. (1996) observed an effect of a $\kappa$-casein gene polymorphism on growth traits in Hereford beef cattle.

The objectives of the present study were to estimate the allele and genotype frequencies of CSN3 and LGB gene polymorphisms in beef cattle belonging to different genetic groups and to determine the effects of these polymorphisms on production traits in these animals which are submitted to a "super-young" production model.

For this purpose, blood was collected from 384 bulls belonging to four different genetic groups and differing in frame size, including 79 Nelore, 30 Canchim (5/8 Charolais $+3 / 8 \mathrm{Zebu})$ and 275 crossbred cattle originating from crosses of Simmental $(n=30)$ and Angus $(n=245)$ sires with Nelore females.

Calves were weaned at 210 days of age using a creep-feeding system. At the beginning of the study, the animals were individually identified, treated against endoand ectoparasites, divided into groups of five animals each in pen according to breed and size, and fed diets formulated according to the recommendations of the National Research Council (NRC, 1996) for an average daily gain higher than $1.2 \mathrm{~kg}$. After entering the pen, the animals were allowed to adapt for a period of approximately 20 days. The 
animals were slaughtered after an average feedlot period of 110 days, presenting a minimal live weight of $450 \mathrm{~kg}$, and aged slightly over one year.

The animals were weighed at the time of entry in the pen (BW0), at the beginning of feedlot (BW1), and close to the time of slaughter (BWEND). Average daily gain (ADG) was calculated for the interval between the last two weight measurements. Upon the last weight measurement, ribeye area (REA) or longissimus dorsi area, and backfat thickness (BT) were assessed by ultrasound, according to the method described by Perkins and modified by Gresham (1998). Dressed percentage (DP) and carcass weight (CW) were measured at slaughtering.

Five milliliters of whole blood were collected by puncture of the left jugular vein in the neck region into vacuum tubes containing $7.5 \mathrm{mg}$ of EDTA. Genomic DNA was extracted from a $300 \mu \mathrm{L}$ aliquot of whole blood, using the Genomic Prep ${ }^{\mathrm{TM}}$ Blood DNA Isolation kit (Amersham Biosciences, Piscataway, NJ, USA). The amount and integrity of the DNA were determined on $0.8 \%$ agarose gel.

The animals were genotyped for the CSN3 and LGB genes by PCR-RFLP. The A and B alleles of the CSN3 gene (chromosome 6) were identified based on the amplification of a 350-bp fragment located between nucleotide 201 of exon IV and nucleotide 149 of intron IV, using the forward primer 5'-ATCATTTATGGCCATTCCACCAA AG-3' and the reverse primer 5'-GCCCATTTCGCTTTCT CTGTAACAGA-3', followed by digestion with the restriction enzyme Hinfl (Medrano and Cordova, 1990a). For the determination of the A and B alleles of the LGB gene (chromosome 11), a 247-bp fragment located between nucleotide 23 of exon IV and nucleotide 158 of intron IV was amplified, which contains a polymorphism at the HaeIII restriction site, was amplified using the forward primer 5'-TGTGCTGGACAGCGACTACAAAAAG-3' and the reverse primer 5'-GCTCCCGGTATATGACCACCCT CT-3' (Medrano and Cordova, 1990b).

Each PCR was performed in a final volume of $25 \mu \mathrm{L}$, with the amplification mixture consisting of $50 \mathrm{ng}$ genomic DNA, $0.20 \mu \mathrm{M}$ of each primer, $10 \mathrm{mM}$ Tris- $\mathrm{HCl} \mathrm{pH} 8.0$, $50 \mathrm{mM} \mathrm{KCl}, 2.0 \mathrm{mM} \mathrm{MgCl} 2,0.2 \mathrm{mM}$ of each dNTP, and $1 \mathrm{U}$ Taq DNA polymerase. DNA was amplified in five steps: 1) initial denaturation of the double strand at $94{ }^{\circ} \mathrm{C}$ for $4 \mathrm{~min}$; 2) denaturation at $94{ }^{\circ} \mathrm{C}$ for $1 \mathrm{~min}$; 3) annealing of the primers at $56{ }^{\circ} \mathrm{C}$ for $45 \mathrm{~s}$; 4 ) extension at $72{ }^{\circ} \mathrm{C}$ for $1 \mathrm{~min}$; and 5) a final extension at $72^{\circ} \mathrm{C}$ for $4 \mathrm{~min}$. Steps 2,3 and 4 , corresponding to one cycle, were repeated 35 times.

The amplified fragments were digested in a reaction mixture containing $10 \mu \mathrm{L}$ of the PCR product and 2.5 and $5 \mathrm{U}$ of the restriction enzymes Hinfl and HaeIII, respectively. The digestion mixtures were incubated for $4 \mathrm{~h}$ in a thermocycler at $37{ }^{\circ} \mathrm{C}$. After digestion of the amplified products, the DNA fragments were separated on $3 \%$ agarose gel, in a horizontal electrophoresis system. A 100-bp molecular weight standard was applied to each gel, to permit the calculation of the size of the amplified and digested fragments. The DNA fragments were visualized on the agarose gel by staining with ethidium bromide followed by exposure to ultraviolet light. The gels were photographed for later analysis of the data, using a digital photodocumentation system. The genotypes of the individuals were determined for each polymorphism by analyzing the size of the fragments reported as base pairs (bp).

Genotype and allele frequencies were calculated according to Weir (1996) for each polymorphism, based on the genotypes identified on the gels. Differences in the allele frequencies of the polymorphisms within and between genetic groups were determined by the method of Goodman, adapted by Curi and Moraes (1981).

The traits of interest were analyzed by least square variance analysis (significance at 0.05 ) using the General Linear Model (GLM) procedure of the SAS program (Statistical Analysis System, 1999). The linear model used to fit the quantitative variables included, in addition to the genotype effect, the contemporary group effect that considered the interaction between genetic groups $(1, . ., 4)$, feedlots $(1, . ., 3)$ and farms of origin $(1, . ., 6)$, as follows: $Y_{i j k}=\mu+\mathrm{G}_{i}$ $+\mathrm{GC}_{j}+\mathrm{e}_{i j k}$, where $\mathrm{Y}_{i j k}=$ production trait, $\mu=$ overall mean, $\mathrm{G}_{i}=$ fixed effect of the $i^{\text {th }}$ genotype, $\mathrm{GC}_{j}=$ fixed effect of the $j^{\text {th }}$ contemporary group, and $\mathrm{e}_{i j k}=$ random error.

Genetic groups showing only one genotype or genotypes with very low frequencies (less than 0.10 ) in the total animal sample were excluded from the analysis. The sire effect was not included in the linear model because the number of genotyped animals which were progenies of the same sires was very small ( 8.5 on average). As a consequence of the large number of small half-sib families, the possibility of confounding the genotype and sire effects on production traits was small.

Two genetic variants (A and $\mathrm{B}$ ) of the CSN3/Hinf 1 polymorphism were identified in the genetic groups studied. Genotype AA was characterized by the presence of three restriction fragments of, respectively, 134, 132 and 84 bp (the 134- and 132-bp fragments could not be separated on the gel under the present conditions). Genotype BB showed two fragments of 266 and $84 \mathrm{bp}$, respectively. Heterozygous individuals $(\mathrm{AB})$ were characterized by the presence of four fragments of 266, 134, 132 and 84 bp, respectively.

Two different alleles (A and B) were found for the LGB/HaeIII polymorphism. Genotype AA was characterized by the presence of two fragments of 148 and $99 \mathrm{bp}$, respectively. Genotype BB was identified based on the presence of two bands of 99 and $74 \mathrm{bp}$, respectively, and three restriction fragments of 99,74 and $74 \mathrm{bp}$, respectively. Heterozygous individuals (AB) showed three bands of 148,99 and $74 \mathrm{bp}$, respectively.

The allele and genotype frequencies of the CSN3/Hinfl and LGB/HaeIII loci obtained for the different genetic groups are shown in Tables 1 and 2, respectively. 
Table 1 - Allele frequencies of the CSN3/HinfI and LGB/HaeIII loci obtained for the four genetic groups and for the sample as a whole.

\begin{tabular}{|c|c|c|c|c|c|c|}
\hline \multirow[t]{2}{*}{ Locus } & \multirow[t]{2}{*}{ Allele } & \multicolumn{4}{|c|}{ Genetic group } & \multirow[t]{2}{*}{ Total } \\
\hline & & Nelore & Canchim & 1/2 Simmental & $1 / 2$ Angus & \\
\hline \multirow[t]{2}{*}{ CSN3/HinfI } & A & $0.892^{\mathrm{A} ; \mathrm{a}}$ & $0.767^{\mathrm{A} ; \mathrm{a}}$ & $0.800^{\mathrm{A} ; \mathrm{a}}$ & $0.782^{\mathrm{A} ; \mathrm{a}}$ & 0.806 \\
\hline & B & $0.108^{\mathrm{B} ; \mathrm{a}}$ & $0.233^{\mathrm{B} ; \mathrm{a}}$ & $0.200^{\mathrm{B} ; \mathrm{a}}$ & $0.218^{\mathrm{B} ; \mathrm{a}}$ & 0.194 \\
\hline \multirow[t]{2}{*}{ LGB/HaeIII } & A & $0.160^{\mathrm{B} ; \mathrm{b}}$ & $0.550^{\mathrm{A} ; \mathrm{a}}$ & $0.400^{\mathrm{A} ; \mathrm{a}}$ & $0.226^{\mathrm{B} ; \mathrm{b}}$ & 0.261 \\
\hline & B & $0.840^{\mathrm{A} ; \mathrm{a}}$ & $0.450^{\mathrm{A} ; \mathrm{b}}$ & $0.600^{\mathrm{A} ; \mathrm{b}}$ & $0.774^{\mathrm{A} ; \mathrm{a}}$ & 0.739 \\
\hline
\end{tabular}

${ }^{\mathrm{A}, \mathrm{B}}$ significantly different allele frequencies within genetic groups $(\mathrm{p}<0.05)$.

${ }^{\mathrm{a}, \mathrm{b}}$ significantly different allele frequencies between genetic groups $(\mathrm{p}>0.05)$.

Table 2 - Genotype frequencies of the CSN3/HinfI and LGB/HaeIII loci obtained for the four genetic groups and for the sample as a whole.

\begin{tabular}{|c|c|c|c|c|c|c|}
\hline \multirow[t]{2}{*}{ Locus } & \multirow[t]{2}{*}{ Genotype } & \multicolumn{4}{|c|}{ Genetic group } & \multirow[t]{2}{*}{ Total } \\
\hline & & Nelore & Canchim & 1/2 Simmental & 1/2 Angus & \\
\hline \multirow[t]{3}{*}{ CSN3/HinfI } & AA & 0.810 & 0.633 & 0.633 & 0.588 & 0.641 \\
\hline & $\mathrm{AB}$ & 0.177 & 0.267 & 0.333 & 0.388 & 0.331 \\
\hline & $\mathrm{BB}$ & 0.013 & 0.100 & 0.034 & 0.024 & 0.028 \\
\hline \multirow[t]{3}{*}{ LGB/HaeIII } & AA & 0.000 & 0.200 & 0.133 & 0.025 & 0.052 \\
\hline & $\mathrm{AB}$ & 0.321 & 0.700 & 0.533 & 0.403 & 0.417 \\
\hline & $\mathrm{BB}$ & 0.679 & 0.100 & 0.334 & 0.572 & 0.531 \\
\hline
\end{tabular}

Segregation of the CSN3/Hinfl polymorphism was observed in the four genetic groups studied, the frequency of allele A being significantly higher than that of allele B in all groups. No significant differences in allele frequencies were observed between the various genetic groups. Genotypes $\mathrm{AA}, \mathrm{AB}$ and $\mathrm{BB}$ for the CSN3/Hinfl polymorphism were detected in all four genetic groups. The homozygous genotype AA predominated over the other two genotypes in all groups, the difference being greater in Nelore animals.

The LGB/HaeIII polymorphism also showed segregation in the four genetic groups. The frequency of allele B was significantly higher than that of allele $\mathrm{A}$ in the Nelore and 1/2 Angus groups, whereas in Canchim and 1/2 Simmental animals the frequencies of alleles $\mathrm{A}$ and $\mathrm{B}$ were similar. The frequency of allele A was lower in the Nelore and $1 / 2$ Angus animals than in the Canchim and 1/2 Simmental groups. No AA genotype for the LGB/HaeIII polymorphism was observed in the Nelore group. Genotypes AA, $\mathrm{AB}$ and $\mathrm{BB}$ showed a heterogeneous distribution in Canchim, 1/2 Simmental and 1/2 Angus animals.

Tables 3 and 4 show the comparison of the least square means and respective standard errors of quantitative growth and carcass traits, respectively, between the genotypes of the CSN3/Hinfl and LGB/HaeIII polymorphisms.

Only genotypes $\mathrm{AA}$ and $\mathrm{AB}$ were considered in the comparative analysis between CSN3/Hinfl polymorphism genotypes. The results showed no significant effects of genotypes on growth: BW0 (p $\leq 0.5024)$, BW1 ( $\leq 0.2473)$, BWEND ( $\leq 0.7566)$ and ADG $(p \leq 0.2609)$ and carcass traits: CW ( $\mathrm{p} \leq 0.1144), \mathrm{DP}(\mathrm{p} \leq 0.5531), \operatorname{REA}(\mathrm{p} \leq 0.8847)$ and BT $(\mathrm{p} \leq 0.1154)$.

The comparative analysis of the LGB/HaeIII polymorphism genotypes only considered genotypes $\mathrm{AB}$ and $\mathrm{BB}$. No significant effects of these genotypes on the quantitative traits analyzed were observed: BW0 ( 150.1564$)$, BW1 ( $\mathrm{p} \leq$ 0.5293), BWEND $(\mathrm{p} \leq 0.8638)$, ADG $(\mathrm{p} \leq 0.9273), \mathrm{CW}(\mathrm{p} \leq 0.4956), \mathrm{DP}(\mathrm{p} \leq 0.3351)$, REA $(\mathrm{p} \leq 0.1551)$ and BT $(\mathrm{p} \leq 0.1651)$.

The CSN3/HinfI polymorphism identified by Medrano and Cordova (1990a) results in the substitutions of the amino acid alanine (allele A) with aspartic acid (allele B) at position 148 in the protein sequence. Thus, this polymorphism has the potential to directly or indirectly affect production traits.

The present results showed high frequencies of allele A, similar to those reported in the literature. Kemenes et al. (1999) and Tambasco et al. (2000) observed frequencies of 0.91 and 0.94, respectively, in Nelore animals. Regitano et al. (1999) found a frequency of 0.67 for the A allele in animals of the Canchim breed. In addition, these and other studies have shown higher frequencies of allele A compared to allele B in both taurine (Ron et al., 1994; Moody et al., 1996; Vasconcellos et al., 2003) and Zebu breeds (Mitra et al., 1998; Kemenes et al., 1999; Tambasco et al., 2000), regardless of whether dairy or beef cattle were studied. This finding indicates that differences in the selection criteria for milk or meat production in these breeds do not favor different alleles of this polymorphism. However, allele $\mathrm{B}$ has been found to predominate in the taurine dairy 
Table 3 - Least square means and standard errors of the growth traits for the genotypes of the CSN3/Hinfl and LGB/HaeIII loci. The number of animals compared in each genotype is given in parentheses.

\begin{tabular}{|c|c|c|c|c|c|}
\hline \multirow[t]{2}{*}{ Locus } & \multirow[t]{2}{*}{ Genotype } & \multicolumn{4}{|c|}{ Growth trait } \\
\hline & & BW0 (kg) & BW1 (kg) & BWEND (kg) & $\mathrm{ADG}(\mathrm{kg})$ \\
\hline \multirow[t]{2}{*}{ CSN3/HinfI } & $\mathrm{AA}$ & $274.25 \pm 2.18(130)$ & $316.89 \pm 1.78(246)$ & $472.27 \pm 2.41(225)$ & $1.48 \pm 0.01(225)$ \\
\hline & $\mathrm{AB}$ & $276.89 \pm 2.97(87)$ & $313.35 \pm 2.46(127)$ & $470.91 \pm 3.49(112)$ & $1.45 \pm 0.02(112)$ \\
\hline \multirow[t]{2}{*}{ LGB/HaeIII } & BB & $276.97 \pm 2.23(109)$ & $314.33 \pm 1.89(205)$ & $471.79 \pm 2.59(183)$ & $1.48 \pm 0.01(183)$ \\
\hline & $\mathrm{AB}$ & $272.04 \pm 2.48(100)$ & $316.11 \pm 2.15(160)$ & $471.10 \pm 2.91(145)$ & $1.47 \pm 0.02(145)$ \\
\hline
\end{tabular}

BW0 = body weight at the time of entry in the pen; BW1 = body weight at the beginning of feedlot; BWEND = body weight at the time of slaughter; $\mathrm{ADG}=$ average daily gain.

No significant differences were observed between genotypes $(\mathrm{p}>0.05)$.

Table 4 - Least square means and standard errors of the carcass traits for the genotypes of the CSN3/HinfI and LGB/HaeIII loci. The number of animals compared in each genotype is given in parentheses.

\begin{tabular}{|c|c|c|c|c|c|}
\hline \multirow[t]{2}{*}{ Locus } & \multirow[t]{2}{*}{ Genotype } & \multicolumn{4}{|c|}{ Carcass trait } \\
\hline & & CW (kg) & DP (\%) & $\operatorname{REA}\left(\mathrm{cm}^{2}\right)$ & BT $(\mathrm{cm})$ \\
\hline \multirow[t]{2}{*}{ CSN3/Hinfl } & AA & $262.07 \pm 1.48(244)$ & $55.61 \pm 0.11(223)$ & $71.82 \pm 0.47(242)$ & $5.07 \pm 0.10(242)$ \\
\hline & $\mathrm{AB}$ & $257.84 \pm 2.03(126)$ & $55.50 \pm 0.16(111)$ & $71.70 \pm 0.64(127)$ & $4.80 \pm 0.14(126)$ \\
\hline \multirow[t]{2}{*}{ LGB/HaeIII } & BB & $259.75 \pm 1.56(204)$ & $55.63 \pm 0.11(182)$ & $71.42 \pm 0.51(203)$ & $4.80 \pm 0.10(202)$ \\
\hline & $\mathrm{AB}$ & $261.34 \pm 1.78(158)$ & $55.49 \pm 0.13(143)$ & $72.51 \pm 0.58(158)$ & $5.00 \pm 0.12(158)$ \\
\hline
\end{tabular}

$\mathrm{CW}=$ carcass weight $\mathrm{DP}=$ dressing percentage REA = ribeye area; $\mathrm{BT}=$ backfat thickness.

No significant differences were observed between genotypes $(p>0.05)$.

breeds Jersey and Brown Swiss (Van Eenennaan and Medrano, 1991). Literature data have demonstrated higher frequencies of the allele A in Zebu breeds compared to taurine breeds. These findings are in accordance to those of the present study, which showed lower frequencies (although non-significant) of allele A in the genetic groups Canchim, 1/2 Simmental and 1/2 Angus as compared to Nelore.

The results obtained in the present study differ from those reported by Moody et al. (1996) in Hereford beef cattle. These authors observed a negative effect of substitution of allele A with allele B of the $\kappa$-casein polymorphism on EPD (Expected Progeny Difference) for birth weight, weaning weight and maternal milk production, indicating that the A allele is favorable to these traits. However, our results agree with those obtained by Regitano et al. (1999) and Tambasco et al. (2003), who did not observe any influence of this polymorphism on growth traits in Canchim beef cattle and F1 animals of Canchim x Nelore, Simmental x Nelore and Angus x Nelore crosses, respectively. According to Pomp et al. (1994), these contradictions can be explained by differences in the linkage equilibrium between markers and quantitative traits loci in the various populations studied, or by different epistatic interactions between the genetic bases of these populations and quantitative trait loci. In addition, epigenetic factors resulting from different experimental conditions may also play a role.

The A and B alleles of the LGB/HaeIII polymorphism were identified by Medrano and Cordova (1990b).
This polymorphism is located in a coding region of the LGB gene (exon IV), leading to changes in the amino acid sequence of the protein and therefore being able to directly or indirectly affect production traits.

In the present study, a low frequency of allele A was observed in the Nelore group compared to the results reported by Rosa (1997), Kemenes et al. (1999) and Tambasco et al. (2000), who found frequencies of $0.41,0.40$ and 0.24 , respectively. However, Faria et al. (2000) reported the same frequency $(0.16)$ as obtained in the present study. This variation in the results might be explained by different selection criteria applied to the herds, or by differences in the allele frequencies between base populations. Regitano et al. $(1999,2000)$ and Vasconcellos et al. (2003) observed frequencies of 0.40, 0.46 and 0.17 for allele A in Canchim, Simmental and Angus breeds, respectively. In other studies, the frequency of the A allele of the $\beta$-lactoglobulin polymorphism was 0.43 and 0.39 in the dairy taurine breeds Holstein and Brown Swiss, respectively (Van Eenennaan and Medrano, 1991), and 0.37 in the Zebu GirGir breed (Kemenes et al., 1999). The allele frequencies of this polymorphism are heterogeneous among breeds and seem to be independent of origin (Zebu or taurine) and type of production (meat or milk).

Although a number of studies have shown a significant effect of the A allele of the LGB/HaeIII polymorphism on milk production (Geldermann et al., 1985; Cowan et al., 1992; Bovenhuis and Weller, 1994), and of the B allele on 
percent milk fat in dairy cattle (Bovenhuis and Weller, 1994), Moody et al. (1996) did not detect any significant effect of this polymorphism on the growth traits of Hereford beef cattle, despite significant allele differences between the selected and the control populations. Regitano et al. (1999) did not observe allele variations between different generations of a Canchim herd and suggested that this polymorphism is not associated with phenotypic traits subjected to selection in this herd. Similarly, Tambasco et al. (2003) did not observe an isolated influence of the LGB/HaeIII polymorphism on the growth traits of crossbred Canchim $\mathrm{x}$ Nelore, Simmental x Nelore and Angus x Nelore cattle. However, these authors found a significant interaction (epistasis) between this marker and a polymorphism of the growth hormone gene influencing weight gain. The same authors called attention to the importance of epistasis studies and of the influence of the $\beta$-lactoglobulin polymorphism on weight gain.

\section{Acknowledgments}

The authors thank Universidade Estadual Paulista (UNESP) for providing the infrastructure for this study, and Fundação de Amparo à Pesquisa do Estado de São Paulo (FAPESP) for financing the study and for the fellowship granted to Rogério A. Curi.

\section{References}

Bovenhuis H and Weller JI (1994) Mapping and analysis of dairy cattle quantitative trait loci by maximum likelihood methodology using milk protein genes as genetic markers. Genetics 137:267-280.

Cowan CM, Dentine MR and Coyle T (1992) Chromosome substitution effects associated with $\kappa$-casein and $\beta$-lactoglobulin in Holstein cattle. J Dairy Sci 75:1097-1104.

Curi PR and Moraes RV (1981) Associação, homogeneidade e contrastes entre proporções em tabelas contendo distribuições multinomiais. Ciên Cult 33:712-722.

Faria FJC, Guimarães SEF, Mourão GB, Lima RMG and Pinheiro LEL (2000) Análise de polimorfismos do gene da $\beta$-lactoglobulina em vacas da raça Nelore e efeitos sobre o peso à desmama de suas progênies. Arq Bras Med Vet Zootec 52:261-265.

Geldermann H, Pieper U and Roth B (1985) Effects of marked chromosome sections on milk performance in cattle. Theor Appl Genet 70:138.

Gresham JD (1998) Study Guide. Real-Time Ultrasound Training Conference. Bovine Applications. University of Tennessee at Martin, 20 pp.

Kemenes PA, Regitano LCA, Rosa AJM, Packer IU, Razook AG, Figueiredo LA, Silva NA, Etchegaray MA and Coutinho LL (1999) $\kappa$-casein, $\beta$-lactoglobulin and growth hormone allele frequencies and genetic distances in Nelore, Gyr, Guzerá, Caracu, Charolais, Canchim and Santa Gertrudis Cattle. Genet Mol Biol 22:539-541.
Medrano JF and Cordova EA (1990a) Genotyping of bovine kappa-casein loci following DNA sequence amplification. Biotechnology 8:144-146.

Medrano JF and Cordova EA (1990b) Polymerase chain reaction amplification of bovine $\beta$-lactoglobulin genomic sequences and identification of genetic variants by RFLP analysis. Anim Biotechnol 1:73-77.

Mitra A, Schlee P, Krause I, Blusch J, Werner T, Balakrishnan CR and Pirchner F (1998) Kappa-casein polymorphisms in Indian dairy cattle and buffalo: A new genetic variant in buffalo. Anim Biotechnol 9:81-87.

Moody DE, Pomp D, Newman S and MacNeil MD (1996) Characterization of DNA polymorphisms in three populations of Hereford cattle and their associations with growth and maternal EPD in line 1 Herefords. J Anim Sci 74:1784-1793.

NRC (1996) Nutrient Requirement of Beef Cattle. National Academy Press, Washington, DC, 242 pp.

Pomp D (1994) Biotechnology and beef cattle improvement: Myths and realities. Proceedings of Beef Improvement Federation 26th Res Symp Annu Mtg, Des Moines, IA, Iowa, USA, pp 236-241.

Regitano LCA, Azevedo JL, Vencovsky R, Packer IU, Barbosa PF, Rosa AJM, Silva NA, Etchegaray MA and Coutinho LL (1999) Selection for breed-specific growth hormone and IGF-I alleles in a synthetic beef cattle cross, Canchim. Genet Mol Biol 22:531-537.

Regitano LCA, Vasconcellos LPMK, Jacinto E, Tambasco MD, Tambasco DD, Euclides Filho K, Barbosa PF, Packer IU and Coutinho LL (2000) Genetic distances among Aberdeen Angus, Canchim, Caracu, Nelore and Simmental beef cattle breeds. Proceedings of the Global Conference on Conservation of Domestic Animal Breeds, 5, Brasília, DF, Brasil, CD-ROM.

Ron M, Yoffe O, Ezra E, Medrano JF and Weller JI (1994) Determination of effects of milk protein genotype on production traits of Israeli Holsteins. J Dairy Sci 77:1106-1113.

Rosa AJM (1997) Caracterização da raça Nelore e teste de paternidade por marcadores moleculares. MSc Thesis, Universidade de São Paulo, Piracicaba, SP, Brasil.

SAS (1999) Statistical Analysis System, Systems for Windows. SAS Instit. Inc., Cary, NC.

Tambasco DD, Alencar MM, Coutinho LL, Tambasco AJ, Tambasco MD and Regitano LCA (2000) Caracterização molecular de animais da raça Nelore utilizando microssatélites e genes candidatos. Rev Bras Zootec 29:1044-1049.

Tambasco DD, Paz CCP, Tambasco-Studart MD, Pereira AP, Alencar MM, Freitas AR, Coutinho LL, Packer IU and Regitano LCA (2003) Candidate genes for growth traits in beef cattle crosses Bos taurus x Bos indicus. J Anim Breed Genet 120:51-56.

Van Eenennaam A and Medrano JF (1991) Milk protein polymorphisms in California dairy cattle. J Dairy Sci 74:17301742.

Vasconcellos LPMK, Tambasco DD, Pereira AP, Coutinho LL and Regitano LCA (2003) Genetic characterization of Aberdeen Angus cattle using molecular markers. Genet Mol Biol 26:133-137.

Weir BS (1996) Genetic Data Analysis: Methods for Discrete Population Genetic Data. 2nd edition. Sinauer Associates, Sunderland, MA, $445 \mathrm{pp}$.

Associate Editor: Pedro Franklin Barbosa 